\title{
Study to Assess Corporal Punishment among Working Children
}

\author{
${ }^{1}$ Gehad Mohamed Abo El Matty Shahbo, ${ }^{2}$ Bindu Bharathi, \\ Ph.D, MSN, BSN, RN, RM $1, M S N, B S N, R N, R M^{2}$ \\ ${ }^{1}$ Associate Professor of Community Health Nursing, Faculty of Nursing, Port- Said University, Egypt \\ ${ }^{2}$ Faculty of Nursing, Kannur Medical College, Kerala University of Health Sciences, Kerala, India
}

\section{Introduction}

Child abuse and neglect refers to " any physical or mental injury, sexual abuse or exploitation, neglect or maltreatment of a child by a person who is responsible for child's welfare, under circumstances which indicate the child's health or welfare is harmed or threatened"(1). Physical abuse is inflicting a non-accidental physical injury upon a child. This may include burning, hitting, punching, shaking, kicking, beating, or otherwise harming a child ${ }^{(2)}$.

Child labor has received much international attention in recent years, as a form of child abuse that needs urgently to be brought to an end. It is perceived to hinder the rightful development of children, and particularly their education ${ }^{(3)}$.

Nowadays all forms of child abuse gain world wide attention, and many institutions and interested organizations taking so many efforts to overcome this complicated problem, being threatening not only the future of these children, but also the future of the entire community, because these abused children are considered to construct that future.

According to the International Labor Organization (ILO) unfortunately, an estimate of 256 million children, part of their everyday environment is a workplace throughout the world and $98 \%$ of economically active children are found in developing countries. For 171 million (2/3 of these), this workplace contains conditions, activities, or substances that are known to be dangerous and more often than not, the environment of these working children does not contain a school. What it does contain, however, are hazardous conditions including sexual exploitation, overexposure, long working hours, begging, and homelessness to just name a few

Occupational hazards causes not only short-term health effects (mainly injuries, skin problems, etc), but also, most effects are long-term and will only become evident in adulthood. Therefore, they are difficult to measure and to quantify. Cancer, infertility, chronic back pain and IQ reduction are some of the expected longterm outcomes ${ }^{(5)}$.

Corporal punishment is a form of child abuse (a broad category of behavior that also includes sexual abuse, emotional abuse, and neglect) ${ }^{(6)}$ Corporal punishment or inflicting physical pain for the purpose of discipline is an ancient social practice, prevalent in almost all cultures ${ }^{(7)}$. It is an ineffective method of discipline and has major deleterious effects on the physical and mental health of those inflicted. Corporal punishment is a discipline method in which a supervising adult deliberately inflicts pain upon a child in response to a child's unacceptable behavior and/or inappropriate language ${ }^{(8) .}$

\section{I.1 Need and significance of the study}

Information on the numbers of children who die each year as a result of abuse comes primarily from death registries or mortality data. According to the World Health Organization. (2000) there were an estimated 57,000 deaths attributed to homicide among children less than 15 years of age. Global estimates of child homicide suggest that infants and very young children are at greatest risk, with rates for the 0 -4years old age group more than double those of $5-14$ years old. ${ }^{(9)}$.

Accumulated research supports the theory that corporal punishment is an ineffective discipline strategy with children of all ages and, furthermore, that it is often dangerous. Corporal punishment most often produces in its victim's anger, resentment, and low self-esteem. It teaches violence and revenge as solutions to problems, and perpetuates itself, as children imitate what they see adults doing. Research substantiates the following consequences of corporal punishment:

- Children whose bosses use corporal punishment to control antisocial behavior, but they shows more antisocial behavior over a long period of time, regardless of race and socioeconomic status, and regardless of whether the mother provides cognitive stimulation and emotional support ${ }^{(10)}$.

- A consistent pattern of physical abuse exists that generally starts as corporal punishment, and then gets out of control.

- Adults who were hit as children are more likely to be depressed or violent themselves ${ }^{(10) \text {. }}$ 
- The more a child is hit, the more likely it is that the child, when an adult, will hit his or her children, spouse, or friends ${ }^{(11) .}$

- Corporal punishment sends a message to the child that violence is a viable option for solving problems.

- Corporal punishment is degrading, contributes to feelings of helplessness and humiliation, robs a child of selfworth and self-respect, and can lead to withdrawal or aggression

- Children who get spanked regularly are more likely over time to cheat or lie, be disobedient at school, bully others, and show less remorse for wrong doing (11).

- Corporal punishment adversely affects children's cognitive development. Children who are spanked perform poorly on school tasks compared to other children. ${ }^{(12) .}$

The important point we need to address is not the fact that children work, but rather the conditions under which they work. Stopping children from working for their livelihood is likely to do them more harm than good. We need to prevent not the work of children, but the abuse of working children (13).

It is important to realize that reported data about child may be biased, and observation for and reporting of suspected cases should consider suspicious cases from any social classes or age. Nurses and physicians who practice in community settings are sometimes in a position to recognize and intervene in cases of suspected child abuse and also they have a legal responsibility to report suspected or actual cases of corporal punishment and child abuse.

\section{I.2 Statement of the problem}

Study to assess corporal punishment among working children at selected areas of Egypt

I.3 Aim of the study

This study was aimed to assess the corporal punishment among the working children

\section{I.4. Objectives}

1. To assess the demographic data of the working children

2. To identify the types of corporal punishment among working children

3. To recognize the health problems of working children

4. To determine the prevalence of corporal punishment among working children

\section{Research Methodology}

II.2. Research design

A comparative cross- sectional descriptive survey design to determine the prevalence, problems and

the negative effects of physical punishment on the health of children less than 15 years old.

\section{II.3 Setting of the study:-}

The study was conducted in the region of the car repair workshops in Ismalia and Port-Said City.

\section{II.4 Population:-}

\section{Laborer children}

\section{II.5 Sampling Technique}

Simple Random Sampling Technique

\section{II.6 Sample}

Laborer children less than the age of 15 years old and who is working in car Workshops

\section{II.7 Sample size}

The study consisted of two groups, 75 children from Ismailia City and 50 children from Port-Said who working in car repair small workshops.

\section{II.8 Research Tool}

An interview schedule was developed based on the review of relevant literature by the researchers and used to elicit information about:-

1- Demographic data as age, sex, residence, educational level and cause of work.

2- The presence of experienced physical punishment at work.

3- The methods of physical punishment.

4- Type of injuries occurred.

5- Health problems

6- Response of family and witnesses towards corporal punishment.

\section{II.9 Data collection process}

Permission was obtained from the workshop's owners for conducting study in their areas. Children included in the study were interviewed individually using the developed tool in the place of their work. 


\section{II.10 Statistical analysis}

The collected data were coded tabulated and analyzed by using the Statistical Package for Social Science (SPSS). Frequencies, percentages, means and standard deviations for different items were obtained).

\section{Figures And Tables}

Table (1): Distribution of the sample based on age

\begin{tabular}{|c||c|c||c||c|}
\hline \hline Demographic characteristics & \multicolumn{2}{|c|}{ Ismalia $(\mathbf{n}=\mathbf{7 5})$} & \multicolumn{2}{c|}{ Port-Said (n=50) } \\
\cline { 2 - 5 } & $\mathbf{N}$ & $\mathbf{\%}$ & $\mathbf{N}$ & $\mathbf{\%}$ \\
\hline \hline Age in years:- & & & & 16.0 \\
Less than10 years & 18 & 24.0 & 8 & 84.0 \\
10 years \& more & 57 & 76.0 & 42 & \\
\hline Mean & \multicolumn{2}{|c|}{$12.2 \pm 10.2$} & \multicolumn{2}{|c|}{$12.8 \pm 9.2$} \\
\hline \hline
\end{tabular}

Table (1) depicts that $76 \%$ of the subjects are above the age of 10 years in Ismalia but $16 \%$ of the samples below 10 years in Port- said.

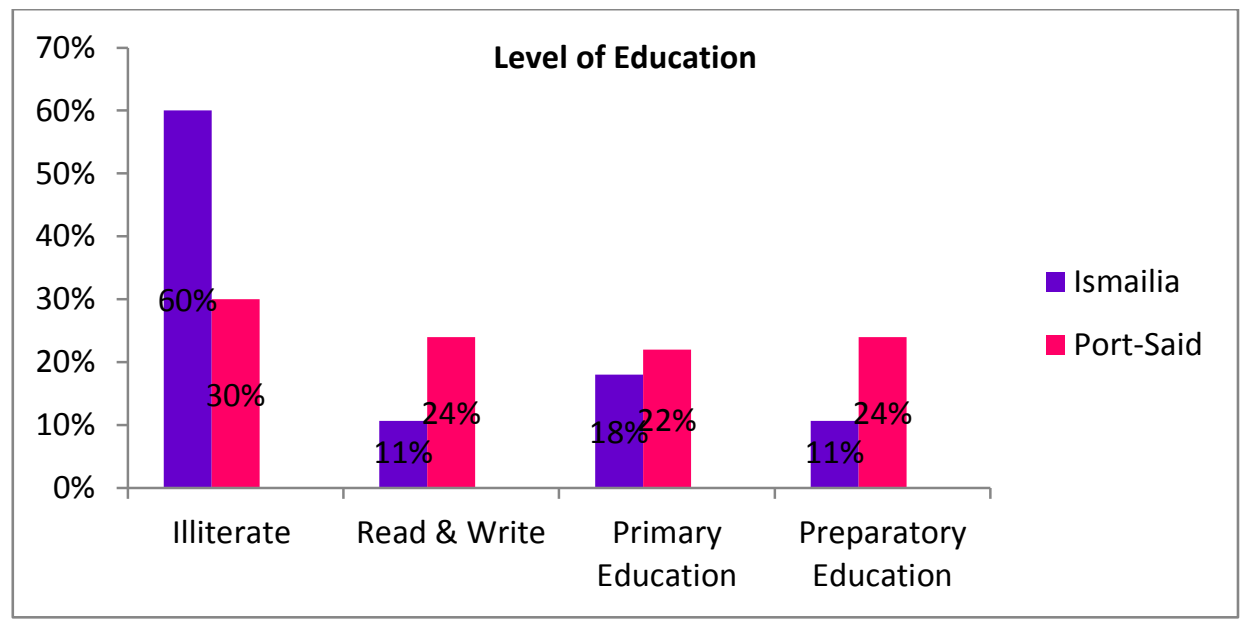

Figure 1: Distribution of sample based on Level of Education

Figure 1 shows that $60 \%$ of study sample were illiterate in Ismalia and $24 \%$ of the subjects have preparatory education in Port-said city.

Table 2: Distribution of the sample according to the reason for Child labor

\begin{tabular}{|c|c|c|c|c|}
\hline \multirow[t]{2}{*}{ Reason for Child labor } & \multicolumn{2}{|c|}{ Ismalia $(n=75)$} & \multicolumn{2}{|c|}{ Port-Said(n=50) } \\
\hline & $\mathbf{N}$ & $\%$ & $\mathbf{N}$ & $\%$ \\
\hline $\begin{array}{l}\text { Family sustenance } \\
\text { Self needs }\end{array}$ & $\begin{array}{l}24 \\
51\end{array}$ & $\begin{array}{l}32.0 \\
68.0\end{array}$ & $\begin{array}{l}30 \\
20\end{array}$ & $\begin{array}{l}60.0 \\
40.0\end{array}$ \\
\hline
\end{tabular}

Table 2 shows that $68 \%$ of the subjects were doing their job for self needs in Ismalia but $60 \%$ of the samples were working for their family in Port- said.

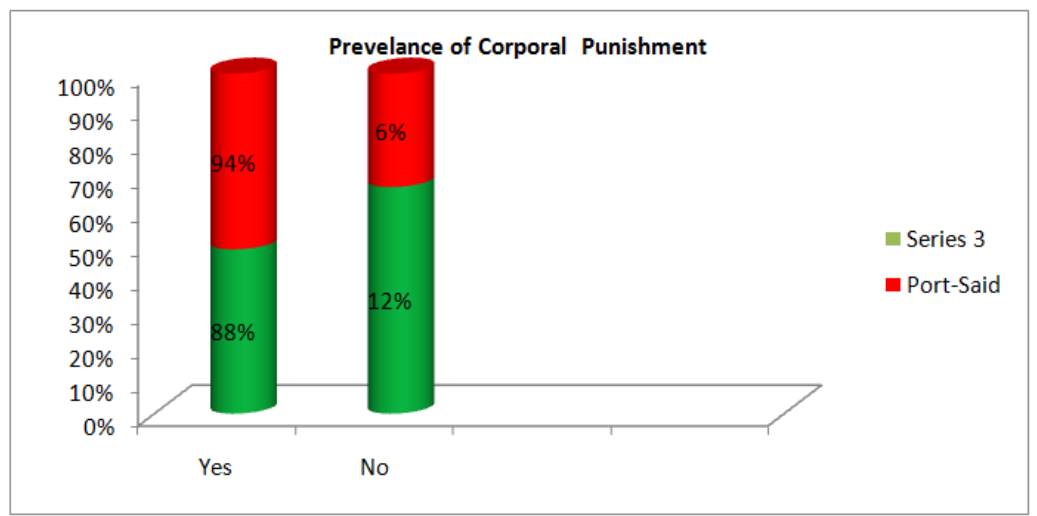

Figure 2: Prevalence of Corporal Punishment among working children. 
Figure 2 depicts that prevalence rate of corporal punishment was 88\% in Ismalia and $94 \%$ in Portsaid city.

Table 3: Distribution of the sample according to Causes Corporal Punishment.

\begin{tabular}{|c|c|c|c|c|}
\hline \multirow[b]{2}{*}{ Corporal punishment. } & \multicolumn{2}{|c|}{ Ismalia $(n=75)$} & \multicolumn{2}{|c|}{ Port-Said( $n=50)$} \\
\hline & $\mathbf{N}$ & $\%$ & $\mathbf{N}$ & $\%$ \\
\hline $\begin{array}{l}\text { Causes:- } \\
\text { Poor work performance } \\
\text { Coming late to work } \\
\text { Didn't do what is to told to do } \\
\text { No clear reason } \\
\text { No Punishment }\end{array}$ & $\begin{array}{c}18 \\
10 \\
16 \\
22 \\
9\end{array}$ & $\begin{array}{l}24.0 \\
13.3 \\
21.3 \\
29.3 \\
12.1\end{array}$ & $\begin{array}{c}17 \\
3 \\
13 \\
10 \\
7\end{array}$ & $\begin{array}{c}34.0 \\
6.0 \\
26.0 \\
20.0 \\
14.0\end{array}$ \\
\hline
\end{tabular}

Table 3 shows that the $24 \%$ and $34 \%$ of the subjects are getting corporal punishment because of poor work performance in Ismalia and Port Said respectively.

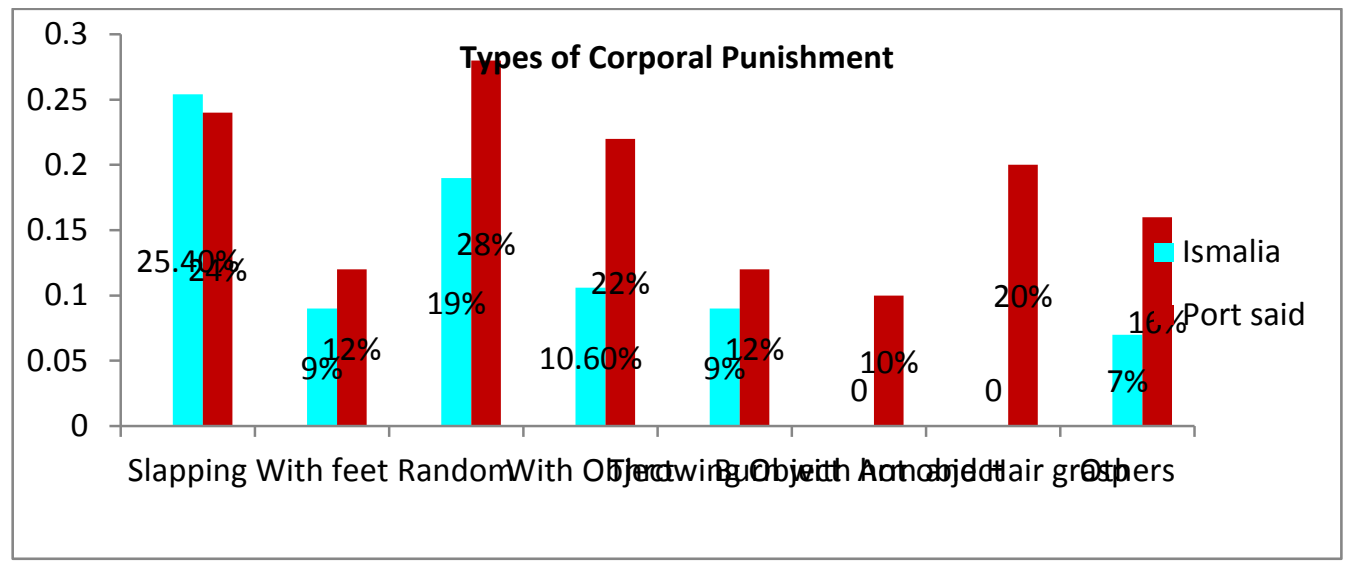

Figure 3 Types of Corporal Punishment

Figure 3 depicts that around $25 \%$ of the sample from both groups are getting slapping, $28 \%$ of the subjects are getting random punishment of Ismalia group $20 \%$ of the subjects from Port said are suffering from arm and hair grasp and $10 \%$ of them are also getting burn with hot objects.

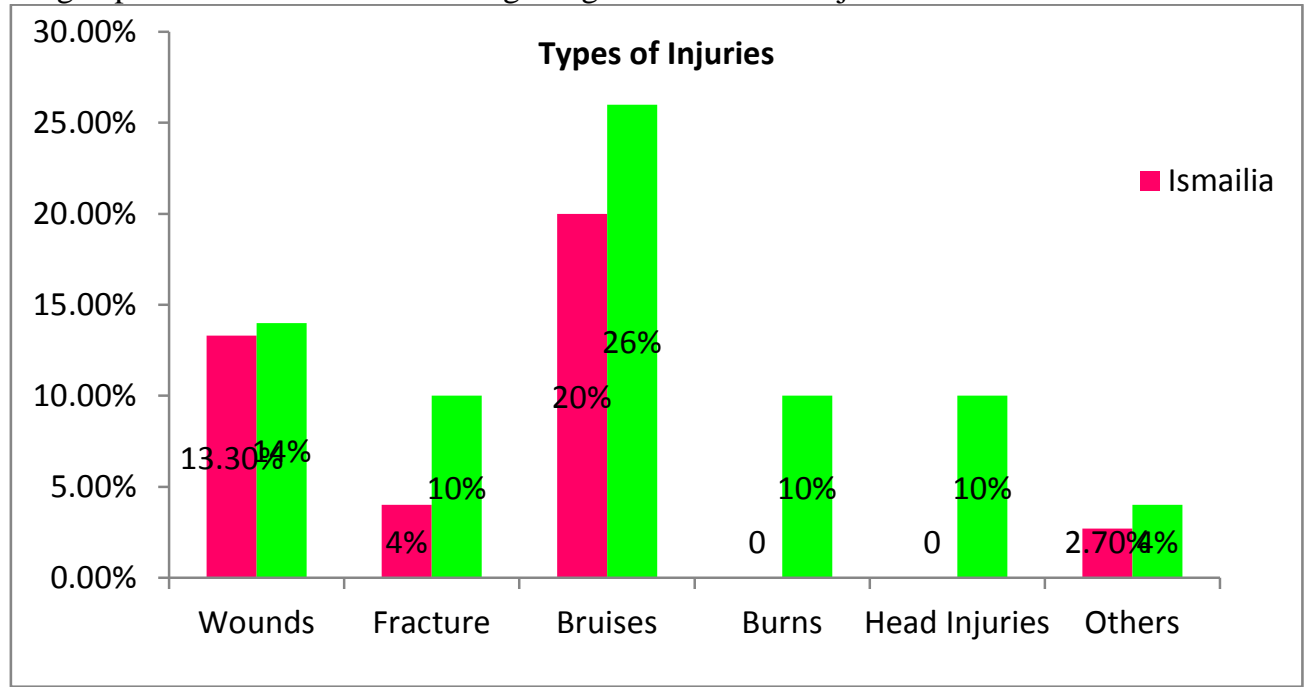

Figure 4: Distribution of the sample based on types of Injuries resulting from corporal punishment.

Figure 4 illustrates that $20 \%$ and $26 \%$ of the samples are getting bruises and abrasions among Ismalia and Port- said groups respectively. Around $14 \%$ of the samples of both groups are suffered from wounds. 10 $\%$ of the samples from Port- said city were experiencing burns and head injuries. 
Table 4: Distribution of the sample based on need and place of treatment

\begin{tabular}{|c||c|c||c||c||}
\hline \multicolumn{1}{|c||}{ Items } & \multicolumn{2}{|c||}{ Ismailia(n=75) } & \multicolumn{2}{c||}{ Port-Said(n=50) } \\
\cline { 2 - 5 } & $\mathbf{N}$ & $\mathbf{\%}$ & $\mathbf{N}$ & \% \\
\hline \hline Needs for treatment:- & & & & 52.0 \\
Yes & 21 & 28.0 & 26 & 48.0 \\
No & 54 & 72.0 & 24 & 100.0 \\
\hline Total & 75 & 100.0 & 50 & \\
Place of treatment:- & & & & 26.0 \\
Home & 14 & 18.6 & 13 & 4.0 \\
Primary health care center & 2 & 02.6 & 2 & 48.0 \\
Hospital & 5 & 06.6 & 11 & 100.0 \\
No & 54 & 72.2 & 24 & \\
\hline Total & 75 & 100.0 & 50 & \\
\hline \hline
\end{tabular}

Table 4 revealed that $28 \%$ and $52 \%$ of the samples from both groups need medical treatment. As regards place of treatment, it was found that $6 \% 22 \%$ of the samples taken treatment from hospitals respectively.

Table 5: Distribution of the sample based on Responses to Corporal Punishment

\begin{tabular}{||c||c|c||c||c||}
\hline \multicolumn{1}{|c|}{ Responses } & \multicolumn{2}{c||}{ Ismailia (n= 75) } & \multicolumn{2}{c||}{ Port-Said ( n= 43 ) } \\
\cline { 2 - 5 } & $\mathbf{N}$ & $\mathbf{\%}$ & $\mathbf{N}$ & $\%$ \\
\hline \hline Quit work:- & & & & \\
Yes & 18 & 24.0 & 25 & 50.0 \\
No & 57 & 76.0 & 25 & 50.0 \\
\hline \hline Family responses:- & & & & \\
Agree & 4 & 05.3 & 19 & 38.0 \\
Disagree & 24 & 32.0 & 16 & 32.0 \\
Didn't know & 38 & 50.6 & 8 & 16.0 \\
No Response & 09 & 12.1 & 07 & 14.0 \\
\hline Witnesses' responses:- & & & & \\
Yes & 6 & 60.0 & 31 & 72. \\
No & 7 & 40.0 & 12 & 27.9 \\
\hline \hline Police notification:- & & & & \\
Yes & 4 & 6.1 & 0 & 0.00 \\
No & 62 & 93.9 & 43 & 100.0 \\
\hline
\end{tabular}

Table 5 shows that $24 \%$ and $50 \%$ quit their job after corporal punishment $32 \%$ of family members are disagree with corporal punishment respectively only few of the witness have respond against corporal punishment and very few cases were reported to the Police.

\section{Results}

1. Among 75 samples, $76 \%$ of the subjects were above the age of 10 years in Ismalia but $16 \%$ of the samples below 10 years in Port- said.

2. $60 \%$ of samples were illiterate in Ismalia and among 50 sample, $24 \%$ of the subjects have preparatory education in Port-said city.

3. $68 \%$ of the subjects were doing their job for meeting self needs in Ismalia but $60 \%$ of the samples were working for their family in Port- said.

4. Regarding prevalence rate of corporal punishment among working children in Ismalia was $88 \%$ and $94 \%$ in Port-said city.

5. $24 \%$ and $34 \%$ of the subjects are experienced corporal punishment because of poor work performance in Ismalia and Port-said respectively.

6. Around $25 \%$ of the samples from both groups are getting slapping, $28 \%$ of the subjects are getting random punishment of Ismalia group, but $20 \%$ of the subjects from Port- said are suffering from arm and hair grasp and $10 \%$ of them are also getting burn with hot objects.

7. About $20 \%$ and $26 \%$ of the samples are getting bruises and abrasions among Ismalia and Port- said groups respectively. Around $14 \%$ of the samples of both groups are suffered from wounds. $10 \%$ of the samples from Port- said city were experiencing burns and head injuries.

8. Regarding medical treatment, $28 \%$ and $52 \%$ of the samples from both groups need medical treatment respectively. As regards to place of treatment, it was found that $6 \%$ and $22 \%$ of the samples taken treatment from hospitals.

9. About $24 \%$ and $50 \%$ of the subjects quit their job after corporal punishment among Ismalia and Port- said respectively. $32 \%$ of families are disagreeing with corporal punishment. Only 
few of the witness have respond against corporal punishment and very few cases were reported to the Police.

\section{Discussion}

In the present study $76 \%$ of the subjects were above the age of 10 years in Ismalia and $16 \%$ of the samples below 10 years in Port- said. This finding is consistent with the percentage of children in the Egyptian labor force has been estimated to be $12 \%$ and economically active children represent $6.5 \%$ of the population for the age group of 6-14 years ${ }^{(14) .}$ Every year, more than 25,000 child laborers under 17 years die as a result of occupational injuries.

In the present study, $60 \%$ of samples were illiterate in Ismalia and $24 \%$ of the subjects have preparatory education in Port-said city. Child workers cannot attend school a precious right that will equip them to build a better future for themselves. ${ }^{(3)}$ All the working children in the small car repair workshops are males and most of them were illiterate.

According to UNICEF ICDC (1999) review of studies on child labor in different countries found that poverty is the most common cause of the work, the same was affirmed by studies in Zambia on child labor. The results of the present study mentioned that most of the study sample of both groups, they are working for sustenance of their families. These results are supporting by DonneII (2003) who stated that parental poverty as the main reason why children are working. Children in a variety of situations have to work for their livelihood. Many families are depends on children's income. Often the schooling of the children depends on the income they earn. Children may work in informal trading enterprises, and either helping their parents or operating on their own account. Some of the children are working in small-scale agriculture in their family plots or the plots of others; children working for their schooling in formal plantations. While all these tasks take up time and energy of the children, and sometimes detract from their schoolwork. This is particularly so when children are the main bread-winners for their families in the absence of able adults.

The results of the present study shows that, the prevalence rate of corporal punishment, among working children to be $88 \%$ \& $94 \%$ respectively among both groups which is higher than the expected rate. $24 \%$ and $34 \%$ of the subjects are getting corporal punishment because of poor work performance in Ismalia and Port Said respectively ${ }^{(8)}$.

In corporal punishment, the adult usually hits various parts of the child's body with a hand or with

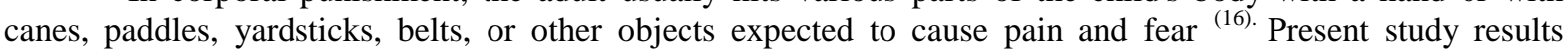
revealed that around $25 \%$ of the samples from both groups are getting slapping, $28 \%$ of the subjects are getting random punishment of Ismalia group, $20 \%$ of the subjects from Port- said are suffering from arm and hair grasp and $10 \%$ of them are also getting burn with hot objects. In the majority of the cases physical abuse is the unintentional end result of harsh disciplinary methods or corporal punishment that have escalated to point of physical injury or the risk of physical injury. Physical abuse often occurs simultaneously with oilier forms of child maltreatment ${ }^{(16)}$.

Current study reports shows that $26 \%$ of the samples are getting bruises and abrasions. Around $14 \%$ of the samples of both groups are suffered from wounds. $10 \%$ of the samples were experiencing burns and head injuries these findings are in line with harm or injuries. Patterns of physical findings that strongly suggest a diagnosis of physical abuse may be bruises on uncommonly injured body surfaces, blunt-instrument marks or burns, human hand marks or bite marks, multiple injuries at different stages of healing, evidence of poor care or failure to thrive, circumferential immersion burns, or unexplained retinal hemorrhages ${ }^{(17) \text {. }}$

In the present study reports shows that $52 \%$ of the samples need medical treatment. As regards place of treatment, it was found that $22 \%$ of the samples taken treatment from hospitals for their physical injuries. Children may he abused by burning, which can result in disfiguring or fatal injuries. Cigarette burns leave centimeter-sized circular marks on the skin. Scald marks on the hands, feet or buttocks that have a glove, sock or circular appearance and spare the intertriginous areas are caused by deliberate immersion of the child in a sink or bathtub of hot water. The presence of excessive splash burns or of scalds on areas of the body not likely to get wet when a child spills a container of hot liquid suggests an inflicted injury ${ }^{(18)}$.

The findings of the present study reported that the police was reported with very few cases of these injuries. In this aspect Maurer (1995) emphasized that Child abuse and neglect are considered a crime. Most institutions providing care to children have a written policy regarding of suspected child abuse. These policies need to be reviewed periodically.

\section{Recommendations}

1. Proper enforcement of law on prevention of Child Labor.

2. Initiate preventive methods of Child abuse at work place

3. Organize awareness class on Prevention of Child abuse and its significance to all workshop owners, parents and public. 
4. Punishment must be applied to the workshop owners if diverged from the "Egyptian Laws and Regulations on the employment of minors".

5. Regular check up and surveillance campaigns should be done to detect corporal punishment and abuses among child laborers.

6. Proper reporting system should be present in the hospitals and other health care centers.

7. Further research about this issue should be carried out on a wider scale to determine the magnitude of the problem and methods of reform.

8. Take possible effort and initiative to prevent the occurrence of corporal punishment and abuses among children through awareness programs.

9. Plan and implement periodical inspection by the Judiciary department to identify the cases of child labor and child abuse.

10. Identification and notification of child labor to the Social Welfare Department, and Police department is also essential.

\section{Conclusion}

It can be concluded that child labor is the major risk factor for childhood abuse. Working children are experiencing different types of corporal punishment and injuries. Thus, it is recommended that must take possible effort and initiative to prevent the occurrence of corporal punishment and abuses among children through awareness programs, and periodical inspection by the legal department.

\section{Acknowledgements}

The authors are grateful to all the children, parents and staff of Car workshops for their participation in the study. The authors also wish to thank Almighty God for accomplishment of this research work.

\section{References}

[1]. U.S. Department of Health and Human Services. (1990); Healthy people 2000: National Health Promotion and Disease Prevention Objectives, Washington D.C., Government printing office.

[2]. National Clearing House on Child Abuse. (2002); Summary from findings calendar year 2000. Retrieved on March 6, 2004 from WWW. Calib. Com/nccanch/ pubs/ factsheets/ canstats.

[3]. DonneII: Department of Balkan, Slavic and Oriental Studies, University of Macedonia, Greece' Eddy Van Doorslaer F. Rosati: Deparment of Health Policy and Management, Erasmus University, The Nether Iands, Health Effects of Children's Work, Understanding Children's Work: an inter-.agency research cooperation project between UNICEF, ILO, and World Book Group, Vietnam. April 2003.

[4]. Mohamed A G, Injuries Among Children Under 16 Years Who Work In Car Repair Small Workshops In Ismailia City, Thesis submitted for partial fulfillment of master degree. Suez Canal University, Faculty of Medicine, Ismailia, Egypt, 1995.

[5]. World Health Organization. The World Report on Violence and Health, , Child abuse and neglect by parents and other caregivers, 2005 .

[6]. Jean G, Moore, Aldershot. The ABC of Child Abuse, Gower, England, 1985.

[7]. Jenny G,Terese H, Kate W. Physical Punishment or Children, Tasmania Law Reform Institution, Tasmania. I ISA. October 2002; paper no. 03.

[8]. Diana B, Berkeley, Robert E, Larzelere. Nebraska Medical Center Philip A. Cowan, Ordinary Physical Punishment: Is It Harmful?, University of California, Berkeley, American Psychological Association Inc. USA, 2002.

[9]. World Health Organization. The World Report on Violence and Health, Chapter 3, Child abuse and neglect by parents and other caregivers, 2002 .

[10]. Gunnoe \& Mariner, 1997; Kazdin, 1987; Patterson, DeBaryshe, \& Ramsey, 1989; ILO, Finding out about Child Labour, Geneva.

[11]. Berkowitz, 1993; Strassberg, Dodge, Pettit, \& Bates, Straus \& Basu, K. Child labor: Cause, consequence and cure with remarks on international labor standards. Journal of Economic Literature, 1999; 37: 1083-1119.

[12]. Straus, Sugarman, \& Giles-Sims. Developmental Psychology, 1997; 29: 44-52.

[13]. Hadi A. Child Abuse Among Working Children In Rural Bangladesh, Prevalence and Determinants, Research and Evaluation Division, BRAC, 1995; Mohakhali. Dhaka 1212. Bangladesh. shirsha@bangla.net.

[14]. Amin T. Health problems among young workers in small and medium size industries. [Doctoral thesis]. Alexandria, Egypt, High Institute of Public Health, Alexandria University, 1992;93.

[15]. UNICEF,ICDC. Child Domestic Work. innocent; digest compiled by UNICEF Florence, Italy, 1999.

[16]. Lesia O, Specialist, and Karen S. Understanding Child Abuse And Neglect, Extension Human Development and Family Studies, Iowa Slate University. USA, 2002.

[17]. Presscl M, David, MD. Evaluation of Physical Injury in Children, USA, May, 2000.

[18]. Carol D. Berkowitz, MD.Los Angeles. Donald C, Bross JD, PhD, Denvel DI, Chadwick, MD, San Diego; and JM. Whitwoith, MD. Diagnostic and Treatment Guidelines on: Child Physical Abuse and Neglect, American Medical Association, USA, March, 1992.

[19]. Maurer FA. Violence : A social and family problem. In C.M. Smith and F.A. Maurer (Eds.). Community Health Nursing: Theory and practice. Philadelphia, W.B. Saunders, 1995; 